\title{
ESTUDO DO COMPORTAMENTO DO CONCRETO POROSO
}

\author{
Nathalia de Trói Silva (IC); Rosa C. Cecche Lintz (PQ)
}

\section{Resumo}

Atualmente existem muitos estudos sobre concreto poroso e suas possibilidades de soluções urbanas e ecológicas em andamento. As peças drenantes oferecem muitas aplicações benéficas à sociedade contemporânea, sendo um material com composição sustentável e também antiderrapante, o que deixa a sua instalação ainda mais viável para garagens, jardins, calçadas e caminhos externos. Foram testados 2 traços de concreto através da variação da quantidade de brita. Dessa forma, foram moldados corpos de prova e ensaiados à compressão e à tração.

Palavras Chave: Materiais Alternativos, Materiais e Componentes da Construção, Processos Construtivos.

\section{Introdução}

Além de práticos, resistentes e duradouros, os pisos drenantes garantem a formação de uma superfície sólida, capaz de suportar veículos pesados. Graças ao seu sistema de drenagem, o revestimento impede 0 acúmulo de água da chuva sobre o solo e usa a absorção como um meio de formar ou abastecer os lençóis freáticos. Foram desenvolvidos dois traços de concreto poroso. As proporções utilizadas foram cimento:brita:água, respectivamente: Traço 1(1:3:0,325) e Traço 2 $(1: 4,5: 0,325)$. Com os respectivos traços, foram moldados corpos de prova cilíndricos e prismáticos e realizados ensaios, como 0 de Resistência à Compressão (NBR 5739).

\section{Resultados e Discussão}

Os resultados dos ensaios de resistência estão apresentados no gráfico 1.

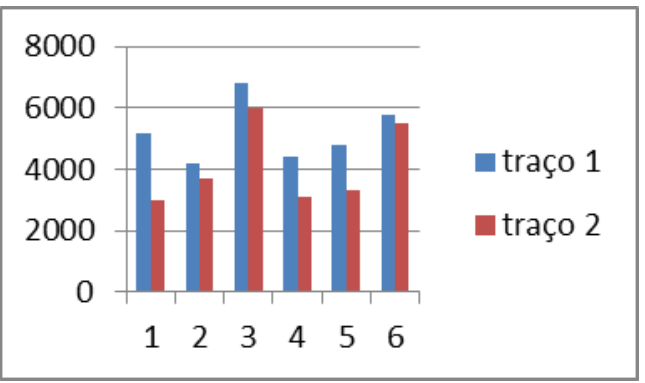

Gráfico 1: Cargas(em Kgf) de Resistência à Compressão em corpos de prova cilíndricos.
Com continuidade aos resultados da primeira pesquisa realizada sobre concreto poroso, a adição de menor quantidade de brita ao concreto (traço 1), proporciona-lhe maior resistência a compressão.

\section{Conclusões}

Conclui-se que a alteração na proporção de brita do traço de concreto é o principal fator determinante para a resistência a compressão dos corpos de prova. E portanto, foi demonstrado que o traço contendo menor teor de brita, confere maior resistência a compressão ao concreto poroso. Além de seu uso contemporâneo, esperase que no futuro o pavimento poroso possa ser solução em grande escala para diversos problemas urbanos e ambientais.

\section{Agradecimentos}

Agradeço a minha orientadora Rosa C.C. Lintz

Associação Brasileira de Normas Técnicas

"O que é piso drenante", encontrado no site:www.mundodastribos.com.br acesso em 09 de abril de 2013 ás $10 \mathrm{~h}$ e $50 \mathrm{~min}$.

STOVIN,Virginia.2010.The potential of Green roofs to manage Urban Stormwater. Water and Environment Journal.v.23,n.3,p 192197.

PALLA, Anna; GNECCO, Ilaria; LANZA, Luca G. 2010. Hydrologic restoration in the urban environment using green roofs. Water. Basel, v.2, p. 140-154. 